\title{
Polymyalgia rheumatica development in a patient under PI3K inhibitor therapy for chronic lymphocytic leukaemia
}

\author{
Sanah Sajawal, ${ }^{1}$ Sarah L Mackie, ${ }^{2}$ Peter Hillmen, ${ }^{3}$ Dennis McGonagle ${ }^{4}$
}

${ }^{1}$ Chapel Allerton Hospital, Leeds Institute of Rheumatic and Musculoskeletal Medicine, University of Leeds, Leeds, UK ${ }^{2}$ Leeds Institute of Rheumatic and Musculoskeletal Medicine, University of Leeds, Leeds, UK ${ }^{3}$ Department of Haematology, St James's University Hospital, Leeds, UK

${ }^{4}$ NIHR Leeds Musculoskeletal Biomedical Research Unit, Leeds Institute of Rheumatic and Musculoskeletal Medicine, University of Leeds, Leeds, UK

\section{Correspondence to \\ Dr Sanah Sajawal,}

ssajawal@nhs.net

Accepted 22 October 2017

\section{SUMMARY}

We report a patient with chronic lymphocytic leukaemia (CLL) who was treated with idelalisib, a PI3K $\delta$ inhibitor with rituximab. After 20 weeks of treatment, the patient developed classical signs and symptoms of polymyalgia rheumatica (PMR) in association with an elevated $C$ reactive protein of $74 \mathrm{mg} / \mathrm{L}$. After 2 weeks of prednisolone $15 \mathrm{mg}$ daily symptoms had resolved and acute phase markers normalised. To our knowledge, this is the first report of PMR developing as a complication of $\mathrm{PI} 3 \mathrm{~K} \delta$ inhibitor treatment of CLL.

\section{BACKGROUND}

Polymyalgia rheumatica (PMR) is a common inflammatory condition affecting patients older than 50 years. ${ }^{12}$ The classical presentation is with pain and stiffness of the neck, shoulder girdle and hip girdle in association with elevated inflammatory markers. ${ }^{12}$ The diagnosis remains clinical and the pathogenesis remains unknown. It is typically treated with $12.5-25 \mathrm{mg}$ oral prednisolone. ${ }^{2}$ There is a clinical overlap with the related condition giant cell arteritis $(\mathrm{GCA})^{1}$; both conditions are associated with elevated circulating interleukin (IL)-6 levels. Here, we report a case of chronic lymphocytic leukaemia (CLL) that developed PMR following therapy with idelalisib, a PI $3 \mathrm{~K} \delta$ inhibitor, and rituximab.

\section{CASE PRESENTATION}

An 85-year-old Caucasian woman received idelalisib (Zydelig, Gilead Sciences) together with rituximab as part of a clinical trial for patients with previously untreated CLL with chromosome 17p deletion.

The patient had been diagnosed with CLL in January 2013, initially presenting with anaemia, recurrent disseminated herpes zoster and a severe chest infection, without B symptoms. At first, she was managed conservatively. However, over the next 2 years, her CLL progressed, with anaemia, thrombocytopaenia, lymphocytosis, widespread lymphadenopathy and palpable hepatosplenomegaly.

In 2015, she commenced a clinical trial (Gilead GS-US-312-0133; EudraCT no: 2013-00331441) in which rituximab $375 \mathrm{mg}$ was administered intravenously once weekly for 8 weeks with oral idelalisib $150 \mathrm{mg}$ given twice daily continuously throughout the study. Prior to treatment, her haemoglobin $(\mathrm{Hb})$ was $7.5 \mathrm{~g} / \mathrm{dL}$, white cell count
(WCC) $163 \times 10^{9} / \mathrm{L}, \quad$ lymphocytes $160 \times 10^{9} / \mathrm{L}$, platelets $54 \times 10^{9} / \mathrm{L}$ and lactate dehydrogenase (LDH) 777 IU/L (normal range 70-250 IU/L) and her $\mathrm{C}$ reactive protein (CRP) was $15.5 \mathrm{mg} / \mathrm{L}$. Antinuclear antibody was negative, plasma viscosity of $1.85 \mathrm{mPa}-\mathrm{s}, \operatorname{IgM} 0.66 \mathrm{~g} / \mathrm{L}, \operatorname{IgA} 0.18 \mathrm{~g} / \mathrm{L}$ and $\operatorname{IgG}$ $8.8 \mathrm{~g} / \mathrm{L}$. Serum protein electrophoresis revealed an IgG kappa paraprotein.

After 10 weeks of treatment within the clinical trial, she complained of 'bone pains' that she managed with simple analgesia. After 18 weeks of therapy with idelalisib, she presented with increasing pain in her neck, shoulders and thigh muscles, early morning stiffness lasting greater than 1 hour and difficulty getting out of bed. Examination revealed limitation of movement of upper and lower limbs and clinical features suggestive of bilateral subacromial bursitis. There was no clinical evidence of synovitis, myositis or neurological disease.

\section{INVESTIGATIONS}

Blood tests revealed normal creatine kinase and an elevated CRP at $45 \mathrm{mg} / \mathrm{L}$. Autoantibodies including antinuclear antibody (ANA), antineutrophil cytoplasmic antibody (ANCA) and rheumatoid factor were negative. Immunoglobulin levels had remained low since commencing the trial. Complement levels were normal.

\section{DIFFERENTIAL DIAGNOSIS}

Our patient had classical signs and symptoms of PMR; however, clinical challenges exist in distinguishing PMR from other disease mimics, including GCA, infection, malignancy, endocrine disorders and elderly onset rheumatoid arthritis. The most commonly misdiagnosed diseases include malignancy and rheumatoid arthritis. ${ }^{3}$ Relevant tests that help to exclude PMR disease mimics include a negative rheumatoid factor, anticyclic citrullinated peptide antibody, ANA, together with normal levels of thyroid-stimulating hormone, creatine kinase, serum protein electrophoresis and vitamin D.

\section{TREATMENT}

She was initially treated with 2 weeks of $10 \mathrm{mg}$ prednisolone with no symptomatic response and a rise in her CRP to $74 \mathrm{mg} / \mathrm{L}$. The dose of oral prednisolone was therefore increased to $15 \mathrm{mg}$ daily, together with injection of $40 \mathrm{mg}$ methylprednisolone 
(Depo-Medrone) to the subacromial bursa on each side. This resulted in complete resolution of her pain within 3 weeks and a fall in CRP to $5.7 \mathrm{mg} / \mathrm{L}$. This pattern of response to the said dose of glucocorticoid is very characteristic of PMR.

\section{OUTCOME AND FOLLOW-UP}

She followed a prednisolone taper following American College of Rheumatology/European League Against Rheumatism guidelines. Three months from her original presentation, after reducing the prednisolone dose from 10 to $9 \mathrm{mg}$, she had a relapse of symptoms in association with a rise in CRP to $39 \mathrm{mg} / \mathrm{L}$. This responded well to an increase in prednisolone dose to $10 \mathrm{mg}$ daily.

Throughout the above, the patient continued to take idelalisib $150 \mathrm{mg}$ twice a day. Her underlying haematological disease responded extremely well with improvement in her blood indices ( $\mathrm{Hb} 9.8 \mathrm{~g} / \mathrm{dL}$, WCC of $5.17 \times 10^{9} / \mathrm{L}$, lymphocytes $2.05 \times 10^{9} / \mathrm{L}$, platelets $\left.136 \times 10^{9} / \mathrm{L}, \mathrm{LDH} 559 \mathrm{IU} / \mathrm{L}\right)$ and CT scans showing significant reduction in nodal disease.

\section{DISCUSSION}

Idelalisib is a first-in-class inhibitor of phosphatidylinositol-3-kinase $(\mathrm{PI} 3 \mathrm{~K}) \mathrm{p} 110$ isoform $\delta .{ }^{4} \mathrm{PI} 3 \mathrm{~K} \delta$ is highly active in B cell malignancies and plays an essential role in the $\mathrm{B}$ cell receptor pathway signalling and regulates cell proliferation, increased cellular metabolism and resistance to apoptosis. ${ }^{45}$

Idelalisib is used in combination with rituximab as a treatment option for patients with relapsed CLL, has shown an overall response rate of $81 \%$ and overall survival of $91 \%$ at 12 months. ${ }^{6}$ In October 2015, it was approved by National Institute for Health and Care Excellence for patients with untreated CLL with a chromosome $17 \mathrm{p}$ deletion or tumour protein p53 mutation or those with relapsing CLL treated less than 24 months previously. ${ }^{7}$ The $\mathrm{p} 53$ gene is located to the most distal band on the short arm of chromosome 17 (17p13). ${ }^{8}$

Although immunologically mediated events such as enterocolitis, ${ }^{9-11}$ glucocorticoid-responsive hepatitis ${ }^{12}$ and pneumonitis are well-recognised complications of idelalisib therapy, this is the first report of this agent being linked to PMR. There are also no reports to our knowledge of PMR development following rituximab therapy.

The question arises whether rituximab, which works to deplete B cells, contributed to the pathogenesis of PMR. Rituximab has been widely used in autoantibody-associated diseases where to our knowledge it is not associated with development of PMR-like or GCA-like syndromes. Furthermore, there has been a reported case of successful use of rituximab in the treatment of GCA. ${ }^{13}$

There is also evidence of disturbed homeostasis of B cells in patients with newly diagnosed GCA or $\mathrm{PMR}^{14}$ : patients had decreased numbers of $B$ cells compared with patients with untreated rheumatoid arthritis and healthy controls. ${ }^{14}$ Following glucocorticoid-induced remission, the number of B cells normalised and exhibited an enhanced IL- 6 response. ${ }^{14}$ This research helps to add to the discussion of the underlying pathogenesis of PMR.

There are reports of PMR occurring in association with haematological malignancies including CLL. ${ }^{15-19}$ Therefore, a role for the underlying haematological disease in the development of PMR cannot be ruled out. It is also plausible that in this case, the mechanism involved a disease-treatment or treatmenttreatment interaction.
PMR has been reported to occur in patients receiving immunosuppression, for example, a case of a patient on triple therapy (tacrolimus, mycophenolate mofetil and prednisone) for renal transplant. $^{20}$ Two patients were reported to develop PMR/ GCA after treatment with ipilimumab, an antagonist of cytotoxic T-lymphocyte associated protein 4 (CTLA-4) that has immune-potentiating effects. ${ }^{21}$ An agent with the opposite function, CTLA-4-Ig, has reportedly shown intriguing results in early trials for GCA. ${ }^{22}$

PI3K inhibition affects many cell lineages in the immune system. ${ }^{45}$ There is some controversy regarding its effect on regulatory $\mathrm{T}$ cells (Tregs) ${ }^{23} 24$ which normally function to control autoimmunity and inflammation via local action of cytokines such as IL-10, transforming growth factor- $\beta$ and IL-35 which modulate the function of lymphocytes and antigen-presenting cells. $^{24}$ In a mouse model, chronic PI3K inhibition led to the development of colitis and Sjogren's syndrome via suppression of Treg cell function. ${ }^{24}$ Inhibition of Tregs has previously been demonstrated with PI3K-Akt pathway inhibitors. ${ }^{25}$ These resulted in a significant and selective reduction in Tregs in vivo, both in naive and tumour-bearing mice; additionally, the significant antitumour effect observed was shown to be Treg dependent. $^{25}$

Research focusing on $\mathrm{T}$ cell subsets and their role in PMR pathogenesis shows varied results. Previous research suggests a possible relationship between ageing of regulatory $\mathrm{T}$ cells and an increased risk of autoimmunity, cancer and infections in the elderly, however the exact mechanisms underlying this process remain unclear. ${ }^{26}$ It has been reported that premature ageing of effector memory and terminally differentiated CD8 + T together with increased proinflammatory potential of CD8 + Tcell has a role in PMR pathogenesis. ${ }^{27}$ However, no obvious changes in Th-subsets and regulatory $\mathrm{T}$ cells were observed in these patients. ${ }^{27}$ Interestingly, research investigating the role of major $\mathrm{CD} 4+\mathrm{T}$ cell subsets has shown that patients with untreated GCA/PMR had decreased frequency of Treg cells and Th1 cells, but a significantly increased percentage of Th17 cells when compared with healthy controls. ${ }^{28}$

Recent studies have shown that immune checkpoint inhibitors which are immunostimulatory in nature are associated with PMR development which was reported in four cases and where PMR responded to standard therapy. ${ }^{29}$ Off note, the most severe toxicity in the checkpoint inhibitor class of drugs including anti-CTLA-4 and anti-programmed cell death protein 1 (PD-1) and anti-PD-L1 is gut toxicity and this is more common with anti-CTLA- $4 .{ }^{30}$ A key mechanism of action of anti-CTLA-4 is thought to be inhibition of regulatory T cells. ${ }^{31}$ Idelalisib is viewed as predominantly immunosuppressive due to its depletion of immune cells including lymphocytes. The most common severe toxicity with idelalisib is also gastrointestinal toxicity, with diarrhoea occurring in $47 \%$ and fatal and or serious colitis occurring in 14\%-19\%. ${ }^{9-11}$ The apparent association of both checkpoint inhibitors and idelalisib with PMR might be the common denominator that both classes of drug cause immune dysregulation and disrupt regulatory $\mathrm{T}$ cell function.

Several studies have demonstrated the important role of IL-6 in the pathogenesis of PMR and its role in Th17 cell survival and development. A recent review of the literature shows promising options for the future. ${ }^{32}$ Here, tocilizumab used either with prednisolone or alone appeared effective and safe in treating patients with PMR. ${ }^{32}$ Further supporting evidence of anti-IL-6 therapy for PMR may come from an ongoing prospective, openlabel, phase IIa trial of tocilizumab. ${ }^{33}$ 
Learning points

- Polymyalgia rheumatica (PMR) is a very unusual complication of immunosuppression but one of which prescribing clinicians should be aware as it can cause distressing symptoms that are treatable with the correct dose of oral glucocorticoid therapy.

- We suggest that, at least in this case, the mechanism might be related to a reduction in regulatory $T$ cell function.

- This is particularly interesting given recent reports of a hypoproliferating regulatory T cell compartment with impaired function in active giant cell arteritis; in this study, tocilizumab appeared to restore regulatory $T$ cell numbers and activation markers. ${ }^{34}$

- We suggest that the potential role of circulating regulatory T cells in PMR, and its relationship to interleukin-6, requires further investigation.

Acknowledgements The patient was seen at St James's University Hospital, Leeds, West Yorkshire. The patient was involved in a clinical trial- Gilead GSUS-312-01330133; EudraCT Number: 2013-003314-41.

Contributors SS obtained consent from the next of kin; contributed to the planning, literature search and collated the required patient information from the notes; helped to write the summary, background, case presentation, discussion and learning points sections of the manuscript. SS was also involved in the referencing and proof-reading of the manuscript. SLM contributed to the literature search, writing of the background, case presentation, discussion and learning points sections of the manuscript and also helped with referencing and proof-reading of the manuscript. PH contributed to the literature search, writing of the background, case presentation, discussion and learning points sections of the manuscript and also helped with referencing, proof-reading and contacting Gilead informing them of the case report. DMG contributed to the planning, literature search and collated the required patient information from the notes, helped to write the summary, background, case presentation, discussion and learning points sections of the manuscript and also helped with referencing and proof-reading of the manuscript.

\section{Competing interests None declared.}

Patient consent Obtained.

Provenance and peer review Not commissioned; externally peer reviewed.

(c) BMJ Publishing Group Ltd (unless otherwise stated in the text of the article) 2017. All rights reserved. No commercial use is permitted unless otherwise expressly granted.

\section{REFERENCES}

1 Mackie SL, Mallen CD. Polymyalgia rheumatica. BMJ 2013;347:f6937.

2 Dejaco C, Singh YP, Perel P, et al.2015 Recommendations for the management of polymyalgia rheumatica: a European League Against Rheumatism/American College of Rheumatology collaborative initiative. Ann Rheum Dis 2015;74:1799-807.

3 Gonzalez-Gay MA, Garcia-Porrua C, Salvarani C, et al. The spectrum of conditions mimicking polymyalgia rheumatica in Northwestern Spain. J Rheumatol 2000;27:2179-84

4 Yang Q, Modi P, Newcomb T, et al. Idelalisib: First-in-Class PI3K Delta Inhibitor for the Treatment of Chronic Lymphocytic Leukemia, Small Lymphocytic Leukemia, and Follicular Lymphoma. Clin Cancer Res 2015;21:1537-42.

5 Brown JR, Byrd JC, Coutre SE, et al. Idelalisib, an inhibitor of phosphatidylinositol 3-kinase p 110 $\delta$, for relapsed/refractory chronic lymphocytic leukemia. Blood 2014;123:3390-7.

6 Shah A, Mangaonkar A. Idelalisib: A Novel PI3K $\delta$ Inhibitor for Chronic Lymphocytic Leukemia. Ann Pharmacother 2015;49:1162-70.

7 National Institute For Health And Care Excellence. Idelalisib for treating chronic lymphocytic leukaemia. London: NICE, 2016. https://www.nice.org.uk/ guidance/ta359/resources/idelalisib-for-treating-chronic-lymphocytic-leukaemia82602676706245 (accessed 26 Oct 2016)
8 McBride OW, Merry D, Givol D. The gene for human p53 cellular tumor antigen is located on chromosome 17 short arm (17p13). Proc Nat Aca Sci 1986;83:130-4.

9 Balagoni H, Chaudhari D, Reddy C, et al. Idelalisib: a rare cause of enterocolitis. Ann Gastroenterol 2016:29:233-5.

10 Weidner AS, Panarelli NC, Geyer JT, et al. Idelalisib-associated Colitis: Histologic Findings in 14 Patients. Am J Surg Pathol 2015:39:1661-7.

11 Zydelig. Full prescribing information. Foster City, CA: Gilead Sciences Inc, 2014 http://www.gilead.com/ /media/Files/pdfs/medicines/oncology/zydelig/zydelig_pi.pdf (accessed 26 Oct 2016)

12 Lampson BL, Kasar SN, Matos TR, et al. Idelalisib given front-line for treatment of chronic lymphocytic leukemia causes frequent immune-mediated hepatotoxicity. Blood 2016:128:195-203.

13 Bhatia A, Ell PJ, Edwards JC. Anti-CD20 monoclonal antibody (rituximab) as an adjunct in the treatment of giant cell arteritis. Ann Rheum Dis 2005;64:1099-100.

14 van der Geest KS, Abdulahad WH, Chalan P, et al. Disturbed B cell homeostasis in newly diagnosed giant cell arteritis and polymyalgia rheumatica. Arthritis Rheumatol 2014;66:1927-38.

15 von Knorring J, Selroos 0. Polymyalgia rheumatica and chronic lymphatic leukaemia. Scand I Rheumatol 1977:6:145-7.

16 Hamidou MA, Derenne S, Audrain MA, et al. Prevalence of rheumatic manifestations and antineutrophil cytoplasmic antibodies in haematological malignancies. A prospective study. Rheumatology 2000;39:417-20.

17 Espinosa G, Font J, Muñoz-Rodríguez FJ, et al. Myelodysplastic and myeloproliferative syndromes associated with giant cell arteritis and polymyalgia rheumatica: a coincidental coexistence or a causal relationship? Clin Rheumatol 2002:21:309-13.

18 Muller S, Hider SL, Belcher J, et al. Is cancer associated with polymyalgia rheumatica? A cohort study in the General Practice Research Database. Ann Rheum Dis 2014;73:1769-73.

19 Oke AR Sammut L, Hull RG. Musculoskeletal complication of haematological malignancy: Reply. Rheumatology 2016;55:968-81.

20 Banerjee S, Brosnahan G. Polymyalgia rheumatica in a renal transplant patient. J Ark Med Soc 2008:105:115-7.

21 Goldstein BL, Gedmintas L, Todd DJ. Drug-associated polymyalgia rheumatica/giant cell arteritis occurring in two patients after treatment with ipilimumab, an antagonist of ctla-4. Arthritis Rheumatol 2014;66:768-9.

22 Langford CA, Cuthbertson D, Ytterberg SR, et al. A Randomized, Double-Blind Tria of Abatacept (CTLA-4lg) for the Treatment of Giant Cell Arteritis. Arthritis Rheumatol 2017;69:837-45

23 Bruno L, Merkenschlager M. Directing T cell differentiation and function with small molecule inhibitors. Cell Cycle 2008:7:2296-8.

24 Soond DR, Slack EC, Garden OA, et al. Does the PI3K pathway promote or antagonize regulatory T cell development and function? Front Immunol 2012;3:244.

25 Abu-Eid R, Samara RN, Ozbun L, et al. Selective inhibition of regulatory T cells by targeting the PI3K-Akt pathway. Cancer Immunol Res 2014;2:1080-9.

26 Fessler J, Ficjan A, Duftner C, et al. The impact of aging on regulatory T-cells. Front Immunol 2013:4:231.

27 van der Geest K, Abdulahad W, Huitema M, et al. AB0052 Polymyalgia rheumatica is characterized by pro-inflammatory, senescent CD8+T cells. Ann Rheum Dis 2013:71:640.12-640.

28 Samson M, Audia S, Fraszczak J, et al. Th1 and Th17 lymphocytes expressing CD161 are implicated in giant cell arteritis and polymyalgia rheumatica pathogenesis. Arthritis Rheum 2012;64:3788-98.

29 Belkhir R, Burel SL, Dunogeant L, et al. Rheumatoid arthritis and polymyalgia rheumatica occurring after immune checkpoint inhibitor treatment. Ann Rheum Dis 2017:76:1747-50

30 Michot JM, Bigenwald C, Champiat S, et al. Immune-related adverse events with immune checkpoint blockade: a comprehensive review. Eur J Cancer 2016:54:139-48.

31 Curran MA, Montalvo W, Yagita H, et al. PD-1 and CTLA-4 combination blockade expands infiltrating T cells and reduces regulatory T and myeloid cells within B16 melanoma tumors. Proc Natl Acad Sci USA 2010;107:4275-80.

32 Macchioni P, Boiardi L, Catanoso M, et al. Tocilizumab for polymyalgia rheumatica: report of two cases and review of the literature. In: Seminars in arthritis and rheumatism 2013:43:113-8.

33 Lally L, Forbess L, Hatzis C, et al. Brief Report: A Prospective Open-Label Phase lla Trial of Tocilizumab in the Treatment of Polymyalgia Rheumatica. Arthritis Rheumato 2016;68:2550-4

34 Miyabe C, Miyabe Y, Strle K, et al. An expanded population of pathogenic regulatory T cells in giant cell arteritis is abrogated by IL-6 blockade therapy. Ann Rheum Dis 2017:76:898-905. 
Copyright 2017 BMJ Publishing Group. All rights reserved. For permission to reuse any of this content visit http://group.bmj.com/group/rights-licensing/permissions.

BMJ Case Report Fellows may re-use this article for personal use and teaching without any further permission.

Become a Fellow of BMJ Case Reports today and you can:

- Submit as many cases as you like

- Enjoy fast sympathetic peer review and rapid publication of accepted articles

- Access all the published articles

- Re-use any of the published material for personal use and teaching without further permission

For information on Institutional Fellowships contact consortiasales@bmjgroup.com

Visit casereports.bmj.com for more articles like this and to become a Fellow 